\title{
IMPLEMENTATION OF INTEGRATED QUALITY STRATEGIC MANAGEMENT OF ISLAMIC PERSPECTIVE EDUCATION
}

\author{
Erick Yusuf \\ Universitas Ibnu Khaldun Bogor \\ Email: erickyusuf@gmail.com \\ Hasbi Indra \\ Universitas Ibnu Khaldun Bogor \\ Email: hasbi.indra@uika-bogor.ac.id \\ Maemunah Sa'diyah \\ Universitas Ibnu Khaldun Bogor \\ Email: maemunah@fai.uika-bogor.ac.id
}

\begin{abstract}
:
This study aims to describe the implementation of integrated quality strategic management of Islamic education perspective. The method used in this research is a literature study by collecting (material materials) sourced from various books, journals, and other sources. The results of the study indicate that the application of strategic management of integrated quality of Islamic education perspective is that the existence of Islamic educational institutions will be advanced and qualified if the management system implements TQM which in its operation is full of the concept of insan as a whole. The implementation of TQM must of course be preceded by quality planning or insan planning. The planning is actually an application of intentions or something to be realized and desired. Then this quality planning is broken down in benchmarking. Benchmarking is an activity to set standards, both processes and results to be achieved within a certain period. For practical purposes, the standard is reflected from the existing reality.
\end{abstract}

Keywords: Strategic Management, Quality, Education

\section{A. INTRODUCTION}

The occurrence of a shift in the regulation and implementation of the government system in the Republic of Indonesia has had an impact and has an impact on the regulation and implementation of the pattern of education, namely from what was originally centralized to a policy that was decentralized. This is stated in writing in the statutory law on. 22 of 1999 concerning regional autonomy, which has been effectively and officially implemented on January 1, 2001, in fact the implementation of educational activities is operated by the districts and cities (Article 11 paragraph 2) (Indra \& Supraha, 2018).

Education in its form, type and variety has been implemented throughout human history itself, but in reality education that is able to produce quality resources has not been fully realized. We can see this in the existing phenomena, there is always a contradiction between the ideal and the fact between the ideal and the reality. One of the factors causing the contradiction above is the management of the educational institution itself. Besides many other factors, the management factor will greatly determine the productivity and effectiveness of educational institutions. Education as a system will not be able to produce quality output, moreover the educational process is not managed properly. Therefore, education must be managed professionally, in order to be able to compete and be able to answer all global challenges (Hairiyah, 2015). 
The problems of education in Indonesia in general are identified in four main crises, which are related to issues: quality, relevance, elitism, and management. Various quantitative indicators have been put forward in relation to the four issues above, including a comparative analysis that compares the educational situation between countries in the Asian region. These four problems are big, fundamental, and multidimensional problems. This problem occurs in education in general in Indonesia, including Islamic education which is considered to be even more problematic. Therefore, it is very important for national development to focus on improving the quality of education. Quality education will be obtained at quality madrasas or schools, and quality madrasas or schools will produce quality human resources as well (Nizar, 2020).

Functionally, education is basically aimed at preparing people to face the future in order to live more prosperously, both as individuals and collectively as citizens of society, nations and between nations. For adherents of religion, the future includes life in this world and a view of a happy afterlife.

In the Law of the Republic of Indonesia number 20 of 2003 concerning the National Education System (sisdiknas) chapter II article 3 it is stated that National Education functions to develop capabilities and shape the character and civilization of the nation in the context of educating the nation's life, aiming at developing the potential of students to become good human beings. have faith and fear of God Almighty, have noble character, are healthy, knowledgeable, capable, creative, independent, and become democratic and responsible citizens. And in chapter III article 4 paragraph 6 it is stated that the principle of providing education is to empower all components of society through participation in the implementation and control of the quality of education services (Hermanto, 2015).

Therefore, education, especially Islamic education, needs to emphasize the provision of educational inputs such as teachers, curriculum, infrastructure, and learning aids, and so on. This is because improving the quality of education will occur automatically if the educational inputs can be met. When the input already exists, it is necessary to have a good management process to produce good output as well. If a process has been carried out optimally, quality output is no longer just a hope but will be realized (Masyitoh, 2020).

Islam as a universal religion, its teachings cover the fields of faith, worship and muamalah, even for social and individual life. In Islamic teachings to do work must be planned, measurable and directed, (Surat As-Sajdah [32]: 5). As the embodiment of Islamic values, it indicates that something that will be done must be programmed. Islam provides an order of "management values" ranging from the smallest to the largest affairs, from taking care of oneself to taking care of the community, from managing household life to managing the country in the framework of a management so that the goals to be achieved through the vision and mission can be achieved. and can be completed efficiently and effectively.

Management that is based on meeting customer needs and continuous improvement is Total Quality Management. In another sense, Santosa states that Integrated Quality Management (MMT) is a management system that promotes quality as a business strategy and is oriented towards customer satisfaction by involving all members of the organization. The application of MMT in schools is very appropriate, because MMT as a system, MMT not only reduces educational problems, but at the same time as a model that prioritizes continuous improvement, MMT offers new philosophies, methods, and strategies for improving the quality of education (Chadijah, 2019). 
In the current era of globalization which is full of challenges, quality service is one of the focuses of educational institutions to maintain their existence and be able to compete competitively in order to continue to grow and develop. In general, quality is a comprehensive description and characteristics of a field or service that aims to satisfy consumer needs. A good or service can be said to be of high quality by a consumer, but other consumers do not necessarily say the same thing.

Quality management has a very strong relationship with what Islam teaches in the Qur'an and hadith. However, in its application, Muslims are far behind with non-Muslims who do not know the ins and outs of the contents of the Qur'an and hadith. Likewise created everything that exists both in the heavens and on earth. Islam teaches that every human being when doing everything must be itqan which means to be serious, thorough, not half-hearted and wholehearted so that the work becomes neat, beautiful, orderly, and in accordance with what was ordered or should happen. (Wahyuni, 2019).

The point is that in order to provide goodness in the sense of being able to satisfy customers, of course through continuous stages including: a quality process. A quality process can be carried out if human resources work optimally, have commitment and are istiqomah in their work. Without the commitment and istiqomah of human resources in an agency or organization, the agency or organization will not be able to carry out a quality process. Therefore, to carry out a quality process, quality and highly dedicated human resources are needed.

Quality processes need to be carried out by all levels and all lines in an agency or organization. If all human resources in agencies and organizations realize the importance of this, then the quality of an agency or organization can be created. When working, human resources are required not to underestimate the forms of work they do, give meaning to their work, be aware that charity is a mode of existence and in terms of its effects, charity is not meant for God, but for himself.

Based on this, the purpose of this study is to describe the implementation of integrated quality strategic management of Islamic education perspective. there are several studies that examine the implementation of integrated quality strategic management of education, including research conducted by (Laleamu, 2013) which states that the Implementation of Total Quality Management (TQM) needs to be carried out in educational institutions as a form of efforts to improve the quality of education. It is important to carry out the management function in every educational institution. Subsequent research was carried out by (Fathurrohman, 2018) that Total Quality Management in the context of education is a methodological philosophy of continuous improvement, which can provide a set of practical tools to every educational institution in meeting the needs, desires, and expectations of customers, now and in the future.

Thus, the application of strategic management of integrated quality of Islamic education is focused on producing graduates (Muslim intellectuals) who excel in integrating science with Islamic values, based on the implementation of education that is in line with the principles of professionalism and good governance that is integrated with the development of a competitive personality.

\section{B. METHOD}

This research was compiled using the literature study method by collecting (material materials) sourced from various books, journals, and other sources. All materials related to writing this 
article were collected and then studied and understood by the researcher, so that the results of the search were presented in this study systematically and chronologically. The results of this search can be described based on the order in which the researcher's goals have been achieved. By discussing the implementation of integrated quality management in Islamic education perspective.

\section{RESULTS AND DISCUSSION}

\section{Strategic Management of Integrated Quality of Education}

The concept of integrated quality management (Total Quality Management) comes from three words, namely total, quality, and management. The main focus of integrated quality management is quality. Regarding quality as the main focus, there are several definitions of quality. Crosby defines quality as "conformance to requirements" (Hadis, 2010). The word total in Indonesian is often used as a comprehensive or integrated word. The word total (integrated) in integrated quality management emphasizes that everyone in the organization must be involved in continuous improvement efforts (Sallis, 2015).

Fred Smith, CEO of General Express defines quality as the standard performance expected by users of products or services (customers). While the General Service Administration (GSA) defines quality is meeting customer needs at the beginning and every time. The third element of integrated quality management is the word management, which is the initial concept of integrated quality management itself. There are many definitions of management that have been put forward by experts. Etymologically, the word management comes from the English language "management" which means management, leadership, and management (Munir, 2006). Management is a process or framework that involves guiding or directing a group of people toward organizational goals or tangible goals (Terry, 2005).

Integrated Quality Management (Total Quality Management-TQM) is a fundamental and comprehensive value system in managing the organization with the aim of improving performance in a sustainable manner in the long term by paying special attention to achieving customer satisfaction while still paying adequate attention to the fulfillment of the needs of all organizational stakeholders. concerned. Quality problems in TQM require the involvement and responsibility of all parties in the organization (Yuli \& Afriansyah, n.d.).

Barnawi (2017) states that "total quality management" is a term that implies integrated quality management. Total quality management is an attractively packaged total intervention that keeps the organization afloat every time. Integrated quality management is a transformation of quality control management that combines human factors with system factors as a combination of engineering and mechanics. Meanwhile, Omachonu and Ross, (2004) stated that "Total quality management (TQM) is the integrative of all functions and processes within an organization in order to achieve continuous improvement of the quality of goods and services. ".(Indra \& Supraha, 2018)

When viewed from the explanation above, it can be seen that by properly understanding the basic concepts of integrated quality management, it can help the leaders of an organization to fully understand the needs for organizational transformation that must be taken, in order to improve the quality of products and services. Integrated quality management plays a key role to ensure that every activity/individual can create satisfaction and good relationships with 
customers. This is expected to accumulate in organizational performance that focuses on creating quality at every point.

Edward Sallis is of the view that there are several concepts of quality, including: First, quality as an absolute concept. In this concept quality or quality is the achievement of the highest standards in a job, product, and service that is impossible to exceed. Second, quality as a relative concept. In this concept of quality or quality there are still opportunities for improvement. Quality or quality is something that can still be improved. However, if in the improvement stage the implementation of a job has reached certain predetermined standards, then the work is of high quality (Rosyada, 2004). Third, is the quality or quality according to the customer. In this definition quality is something that satisfies and exceeds customer wants and needs. Peters argues that the definition put forward by the customer is very important, because Peters discovered the fact that customers will pay more for good quality, regardless of the type of product (Riyadi, 2007). To understand the concept of quality in integrated quality management, it can be seen in the following picture:

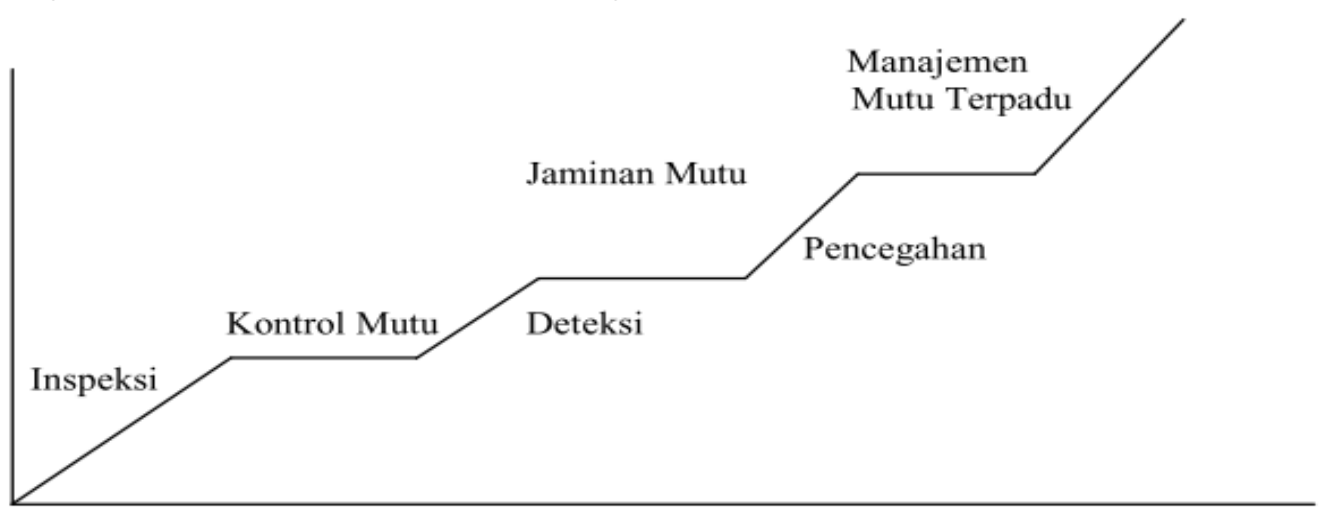

Picture. 1 Quality Concept Hierarchy (Sallis, 2015)

The above hierarchy of quality concepts is adapted to changing customer expectations and styles by designing products and services that meet and satisfy their expectations. By satisfying customers, you can be sure that they will come back again and tell their friends about the product or service. These customer perceptions and expectations are recognized as shortterm and subject to change. Likewise with the organization, it must find the right methods to get closer to their customers in order to respond to their changing tastes, needs and wants.

The implementation of Total Quality Management (TQM) basically involves all personnel in school activities in order to achieve customer satisfaction. To ensure the successful implementation of TQM, there are several steps that must be carried out sequentially and disciplined, namely: (1) instilling a quality philosophy throughout the organization, (2) preparing quality-oriented leadership, (3) making changes or modifications to the existing quality system. , (4) train and empower employees (Rasmi, 2014).

The aim is to improve quality, competitiveness for output (graduates) with indicators of competence, both intellectual and skill as well as high social competence of students/graduates. In achieving these results, the implementation of TQM in educational organizations (schools) needs to be done actually not half-heartedly. By utilizing all the quality entities that exist within the organization, our education will not be where it is today (Asmuni, 2013).

\section{Application of Integrated Quality Management in Islamic Education}


The importance of management in the organization of an organization is absolutely necessary. Various studies have shown that quality management has an effect on company performance. Based on the research, it can be understood that there is a relationship between the dimensions of quality and organizational performance. A study also proves that quality management practices have an influence on the company's performance and competitive advantage.

In Islamic teachings to do work must be planned, measured and directed, (Surat As-Sajdah [32]: 5) as a manifestation of Islamic values indicates that something to be done must be programmed. Education is the main structure that provides facilities for citizens to be able to determine what goods and services are needed (Zamroni, 2011). Even at a macro level, education is the "heart" as well as the "backbone" of the future of the nation and state (Farodis, 2011). The success of a nation is largely determined by its success in improving and renewing the education sector. While on the other hand, the Islamic education system is a crater of candradimuka that forms the perfect human being as the initial foundation in the development of civil civilization, and manifests grace for all mankind (Sukarno, 2011).

In addition to the verse in surah al-Qashash/28: 77 , which is in line with this matter so that humans seek what Allah has given in the form of happiness in this real world and the last day as a blessing that we must pick up with the best activities and do not become the inhabitants of this world do with actions that can destroy the social order that lies on this earth.

So therefore, viewed from the context of managing efforts to improve the quality of education in Islam, a problem can be said to be of quality if it spreads the benefits of virtue, even to itself (the educational institution itself), or other than itself (stakeholders and customers). A person should not work recklessly or not optimally, neglecting activities by relaxing himself, let alone a priori, because it means demeaning the meaning of sincerity from God or demeaning God. In a hadith, the Prophet sallallaahu 'alaihi wa sallam said:

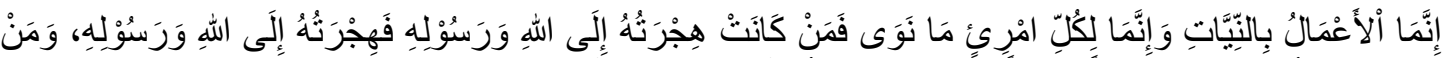

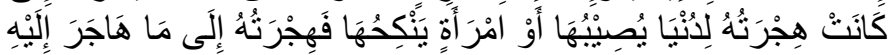

Meaning: "Indeed deeds depend on intentions, and indeed everyone will get according to what he intended. Whoever emigrates for Allah and His Messenger, then he will get the reward of emigration to Allah and His Messenger. Whoever emigrates because of the world that he wants to get or because of the woman he wants to marry, then he gets things according to what he intended." (Narrated by Al Bukhari and Muslim)

The hadith shows that to achieve the level of insan (quality) must be done with quality planning as well (quality planning). The intention is the intention or vibration in the heart. But the intention in the study of fiqh must be accompanied by action, and if it is only a vibration, then it is not an intention but only a desire. Therefore, in the world of Islamic education management, the intention (planning) must be concrete and not abstract so that success can be realized immediately. The above description can be explained in the following figure: 


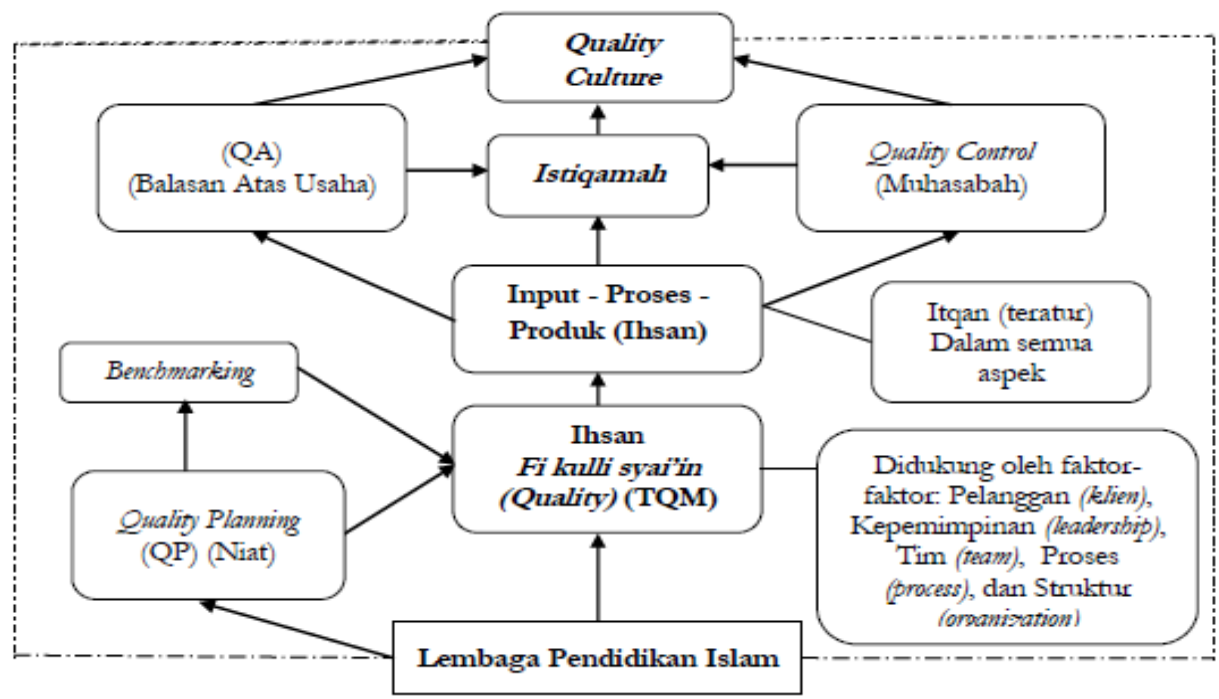

Picture. 2 Quality Development Framework in Islamic Perspective (Fathurrohman, 2018)

Based on the picture of the quality development framework above, it can be explicitly understood that the existence of Islamic educational institutions will be advanced and qualified if the management system implements TQM which in its operation is full of the concept of insan as a whole. The implementation of TQM must of course be preceded by quality planning or insan planning. The planning is actually an application of intentions or something to be realized and desired. Then the quality planning is broken down in benchmarking. Benchmarking is an activity to set standards, both processes and results to be achieved within a certain period. For practical purposes, the standard is reflected from the existing reality.

The application of integrated quality management of Islamic education perspective, among others as follows:

1. Quality education is one of the determinants of the nation's future

The world is developing rapidly today, so quality education is one of the determinants of the nation's future to achieve the ideals mandated in the constitution in the fourth paragraph. Then from that, to form an Indonesian state government that protects the entire Indonesian nation and the entire homeland of Indonesia and to promote public welfare, educate the nation's life, and participate in carrying out world order based on freedom, eternal peace and social justice, and so on.

\section{Character education will give birth to a national culture that brings prosperity}

To educate the nation it is necessary to have an education that has characteristics that reflect a nation that has a high national culture, so that with high education with character it can give birth to common prosperity for all Indonesian people.

3. In the context of Islamic education, there needs to be a reorientation of golden values in da'wah \& education

4. The state must be present to prioritize education by providing a large budget for education 
Article 31 paragraph (1) of the Law on Education and Culture (1) Every citizen has the right to education, (2) Every citizen is obliged to attend basic education and the government is obliged to pay for it, (3) The government seeks and organizes a national education system, which increases faith and piety and noble character in the context of the intellectual life of the nation, which is regulated by law. (4) The state prioritizes the education budget at least twenty percent of the state revenue and expenditure budget as well as from the regional revenue and expenditure budget to meet the needs of the national education administration. (5) The government shall advance science and technology by upholding religious values and national unity for the advancement of civilization and the welfare of mankind.

Thus, the state should carry out education that has characteristics and quality because it has been mandated by the constitution 45 , with a budget that has been allocated by the state of $20 \%$. For 2019 , the budget for the function of education is allocated Rp. 429.5 trillion. these costs are large enough to manage a quality national education system. To educate the Indonesian people and increase the competitiveness of human resources (HR) in the international world, so that they become a developed and respectable country.

\section{Education quality control in accordance with national education standards}

In the implementation of improving the quality of education, there must be someone who guarantees and controls the quality of education so that it is in accordance with the National Education Standards. In this case, the government conducts evaluation, accreditation, and certification. These three processes are carried out to determine whether or not an educational institution with national standards is appropriate.

National Education Standards aim not only to equalize the quality standards of education in the Unitary State of the Republic of Indonesia, but also to meet the demands of local, national and global changes. Because the quality of education in Indonesia has fallen far behind other ASEAN countries, improvements in education will continue to occur. So that the quality of education in Indonesia can compete with other countries.

\section{Differences in the quality of education with other countries}

The difference in the quality of education in Finland which is currently number one in the world with other countries, especially in Indonesia (especially Islamic Education Institutions). Such as being a teacher/teacher becoming a prestigious profession, with an honorarium of 2520 euros or the equivalent of 40 million rupiahs, orientation towards teachers.

In responding to the challenges of the industrial revolution 4.0 there are contradictions in learning in Islamic educational institutions, especially Islamic boarding schools which prohibit the use of gadgets/mobile phones, even though conceptually it is necessary to familiarize students/students to use them so that not only a "lifestyle" is formed but further from that is the formation of a "framework". of thinking" or a digital mindset that can answer future challenges. The problem of the existence of negative impacts or excesses needs to be made a system that can contain controlled students or can control the negative use of these gadgets.

7. Educational goals based on the Constitution

Overall, the educational objectives contained in the 45th Constitution on Education are very textually perfect, but it is necessary to make a grand design to the blue print for the 
implementation problems so that they can be implemented and applied at all levels in educational institutions in Indonesia, especially Islamic educational institutions.

\section{CONCLUSIONS}

Based on the discussion in this study, that the implementation of integrated quality strategic management of Islamic education perspective is an effort to build a quality-oriented organizational culture structure that can be realized in accordance with the expected competency targets. This is like the verses of the Qur'an and various hadiths of the Prophet Muhammad saw which show and hint that a quality culture will be formed and built from the system if it is done with istiqamah.

\section{Reference}

Abdul Hadis, N. (2010). Manajemen Mutu Pendidikan. Alfabeta.

Asmuni. (2013). Konsep Mutu dan Total Quality Manajement (TQM) dalam Dunia Pendidikan. Jurnal Ta"dib, XVIII(01), 16-42.

Chadijah, S. (2019). Implementasi Manajemen Mutu Menurut Al-Qur'an. Jurnal Rausyan Fikr, 15(1), 13-19.

Farodis, Z. (2011). Panduan Manajemen Pendidikan ala Harvard University. Diva Press.

Fathurrohman, M. (2018). Manajemen Mutu Pendidikan Islam Dalam Perspektif Al-Qur'an dan Hadits. AL-WIJDÁN: Journal of Islamic Education Studies, III(2), 190-126.

Hairiyah. (2015). Konsep Manajemen Mutu Terpadu Dalam Pendidikan. Jurnal Literasi, VI(1), $99-110$.

Hermanto, M. (2015). Manajemen Mutu Terpadu Dalam Pendidikan Islam. 1-26.

Indra, H., \& Supraha, W. (2018). Manajemen Mutu Terpadu Dalam Perspektif Pendidikan Islam. Seminar Nasional "Membangun Budaya Literasi Pendidikan \& Bimbingan Dan Konseling Dalam Mempersiapkan Generasi Emas," 143-152.

Laleamu, N. (2013). Implementasi Manajemen Mutu Terpadu (Total Quality Management) Di Lembaga Pendidikan Islam. Institut Agama Islam Negeri (IAIN) Manado, Sulawesi Utara, $1-14$.

Masyitoh. (2020). Manajemen Mutu Pendidikan Perspektif QS. Ar-Ra'du Ayat 11 Impelemnatasinya Dalam Pengelolaan Madrasah. Jurnal Manajemen Pendidikan JUMPA, 1(1), 37-50.

Munir. (2006). Manajemen Dakwah. Kencana.

Nizar, A. (2020). Manajemen Mutu Pendidikan Islam dalam Perspektif Hasan Langgulung. Proceeding of The ICECRS Conference of Management of Islamic Education Leadership in The Era of Revolution 4.0, 6, 1-6.

R.Terry, G. (2005). Dasar-Dasar Manajemen. PT. Bumi Aksara.

Rasmi. (2014). Peningkatan Mutu dan Profil Lembaga Pendidikan dalam Perspektif Total Quality Management (TQM). Jurnal Al-Ta'dib, 7(1), 54-67.

Riyadi, A. A. (2007). Manajemen Mutu Pendidikan. Ircisod.

Rosyada, D. (2004). Paradigma Pendidikan Demokratis; Sebuah Model Perlibatan Masyaraka dalam Penyelenggaraan pendidikan. Kencana.

Sallis, E. (2015). Total Quality Management in Education. Ircisod.

Sukarno. (2011). Budaya Politik Pesantren Perspektif Interaksionisme Simbolik. Interpena.

Wahyuni, A. (2019). Manajemen Mutu Dalam Perspektif Islam. Jurnal Idaarah, III(2), 257-261.

Yuli, D. R., \& Afriansyah, H. (n.d.). Implementasi Manajemen Mutu Terpadu ( Total Quality Management ) di Sekolah.

Zamroni. (2011). Dinamika Peningkatan Mutu. Kalam Utama. 